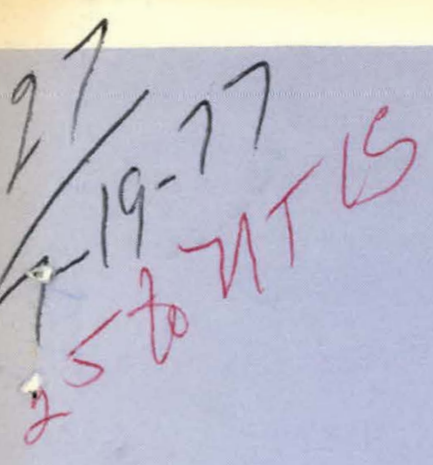

\title{
TATB PBX FORMULATION \\ (Evaluation of Holston Process)
}

A. Gordon Osborn

Thomas L. Stallings

Herbert D. Johnson

DEVELOPMENT DIVISION

MARCH 1977

Process Development

Endeavor No. 106

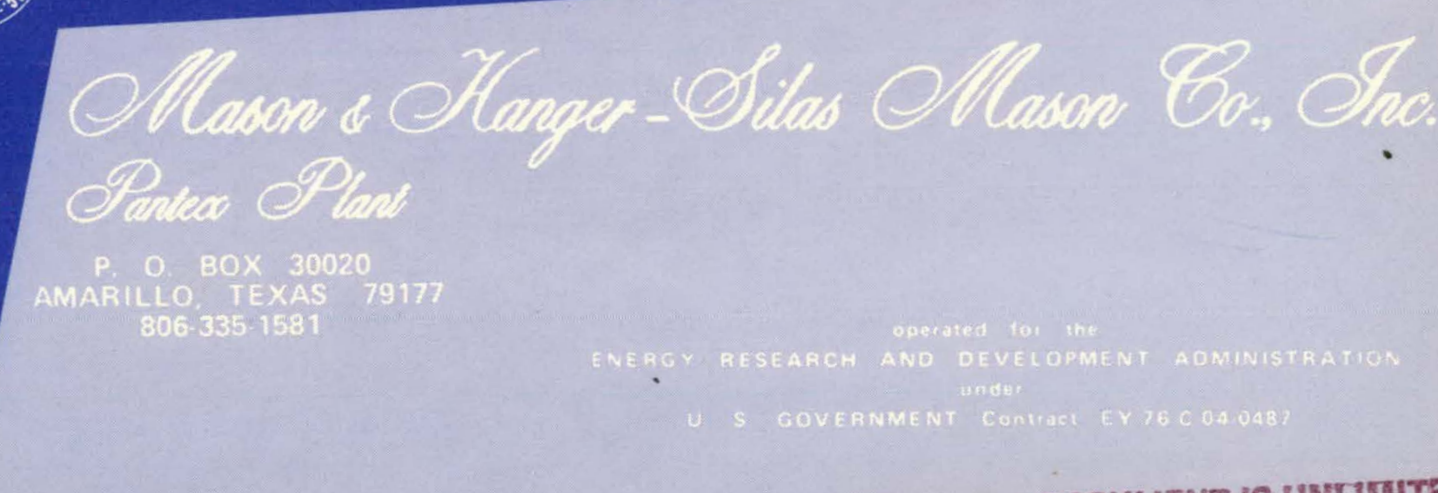




\section{DISCLAIMER}

This report was prepared as an account of work sponsored by an agency of the United States Government. Neither the United States Government nor any agency Thereof, nor any of their employees, makes any warranty, express or implied, or assumes any legal liability or responsibility for the accuracy, completeness, or usefulness of any information, apparatus, product, or process disclosed, or represents that its use would not infringe privately owned rights. Reference herein to any specific commercial product, process, or service by trade name, trademark, manufacturer, or otherwise does not necessarily constitute or imply its endorsement, recommendation, or favoring by the United States Government or any agency thereof. The views and opinions of authors expressed herein do not necessarily state or reflect those of the United States Government or any agency thereof. 


\section{DISCLAIMER}

Portions of this document may be illegible in electronic image products. Images are produced from the best available original document. 
NOTICE

This report was prepared as an account of work sponsored by the United States Government. Neither the United States nor the United States Energy Research and Development Administration, nor their employees, nor any of their contractors, subcontractors, or their employees, makes any warranty, express or implied, or assumes any legal liability or responsibility for the accuracy, completeness or usefulness of any information, apparatus, product or process disclosed, or represents that its use would not infringe privately-owned rights.

Printed in the United States of America Available from

National Technical Information Service

U. S. Department of Commerce

5285 Port Royal Road

Springfield, VA 22161

Price: Printed Copy $\$ 3.50$; Microfiche $\$ 2.25$ 
TATB PBX FORMULATION

\{EVALUATION OF HOLSTON PROCESS\}

A. Gordon Osborn

Thomas L. Stallings

Herbert D. Johnson

DEVELOPMENT DIVISION

Process Development

Endeavor No. 106

\begin{abstract}
Three Holston lots of TATB PBX were tested for physical strength. Two of the lots were LASL X-0290 ( $5 \% \mathrm{Kel}-\mathrm{F}$ ) which used standard aminated TATB while the third lot was made from wet aminated TATB at the $7.5 \% \mathrm{Kel}-\mathrm{F}$ composition. Tensile stress of the wet aminated batch was low. The standard aminated X-0290 lots had acceptable stress and strain.

Three other lots of PBX made at Pantex using the Holston process with standard aminated TATB were also tested for physical strength.
\end{abstract}

\section{INTRODUCTION}

The programatic requirements for TATB PBX will be met by Holston; therefore, it is necessary for Holston produced PBX to have adequate physical strength. Pantex has been involved in the transfer of processing technology to Holston and the evaluation of their material and processing methods.

\section{HOLSTON PROCEDLRE}

The Holston and Pantex processing methods differ as to solvent systems and methods to achieve granulation. The solvent used by Holston is ethyl acetate, which has a reasonably high solubility in water. Basically, a slurry is formed at a low water level with TATB and the 1acquer; then the granules are formed by quenching or by adding water to extract sufficient solvent to cause the granules to form. After an annealing period to solidify the granules, the solvent is stripped by distillation.

\section{EVALUATION OF PBX MADE AT HOLSTON}

Tensile strength data for the three lots made at Holston are given in Fig. 1. A curve for a Pantex produced lot, $\mathrm{B}-14$, is included for comparison. Also additional physical properties information are given in Table I. 


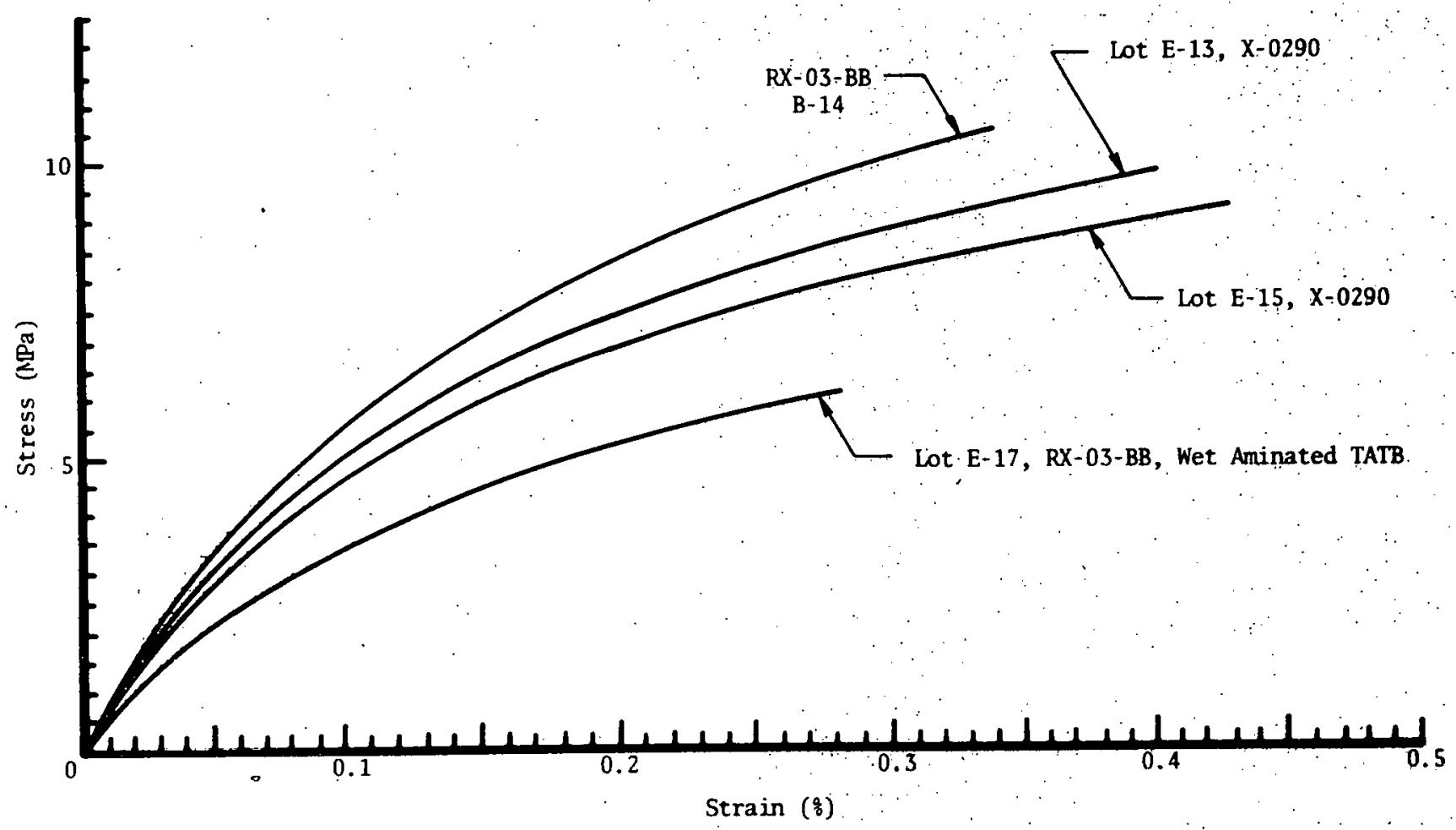

Fig. 1. Holston Made PBX (Tensile Strength)

Table I. Evaluation of. PBX Made at Holston

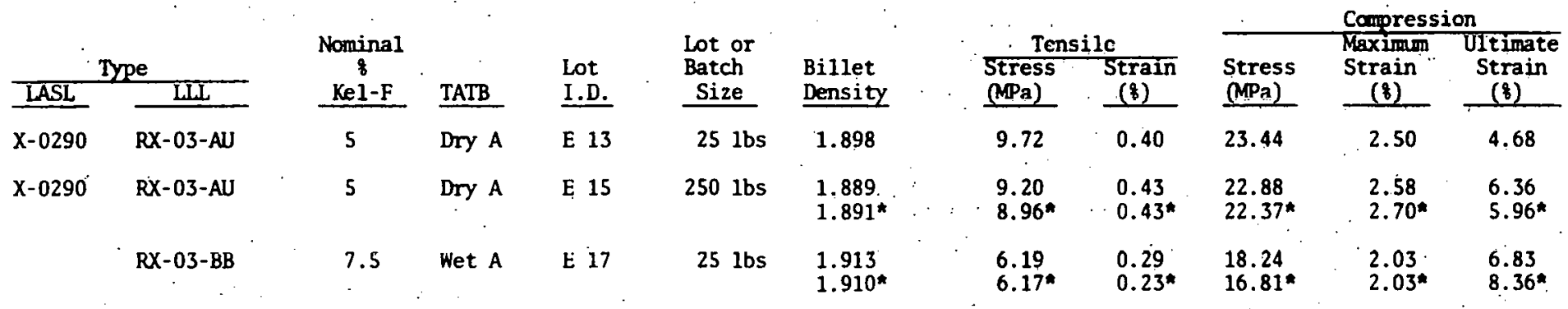


These preliminary physical properties results indicate that the PBX made from standard aminated. TATB has acceptable strength. The strength of the PBX made from wet aminated TATB, however, was too low to be" useful.

\section{EVALUATION OF HOLSTON PROCESS}

Three large batches of TATB PBX (two $\mathrm{RX}-03-\mathrm{BB}$ and one $\mathrm{X}-0290$ ) were made at Pantex from standard aminated TATB in the 300-gallon kettle by the Holston processing method. Tensile strength curves are given in Fig. 2 and additional information shown in Table II. Results appear to be satisfactory.

\section{CONCLUSION}

Preliminary results indicate that the Holston process for making PBX yields material with acceptable physical properties with standard aminated TATB but not with wet aminated material.

An additional series of batches representing approximately 2000 pounds of X-0290 has been received from Holston. Also included is a smal1 25-pound lot of RX-03-BB. Physical properties will be measured for these batches.

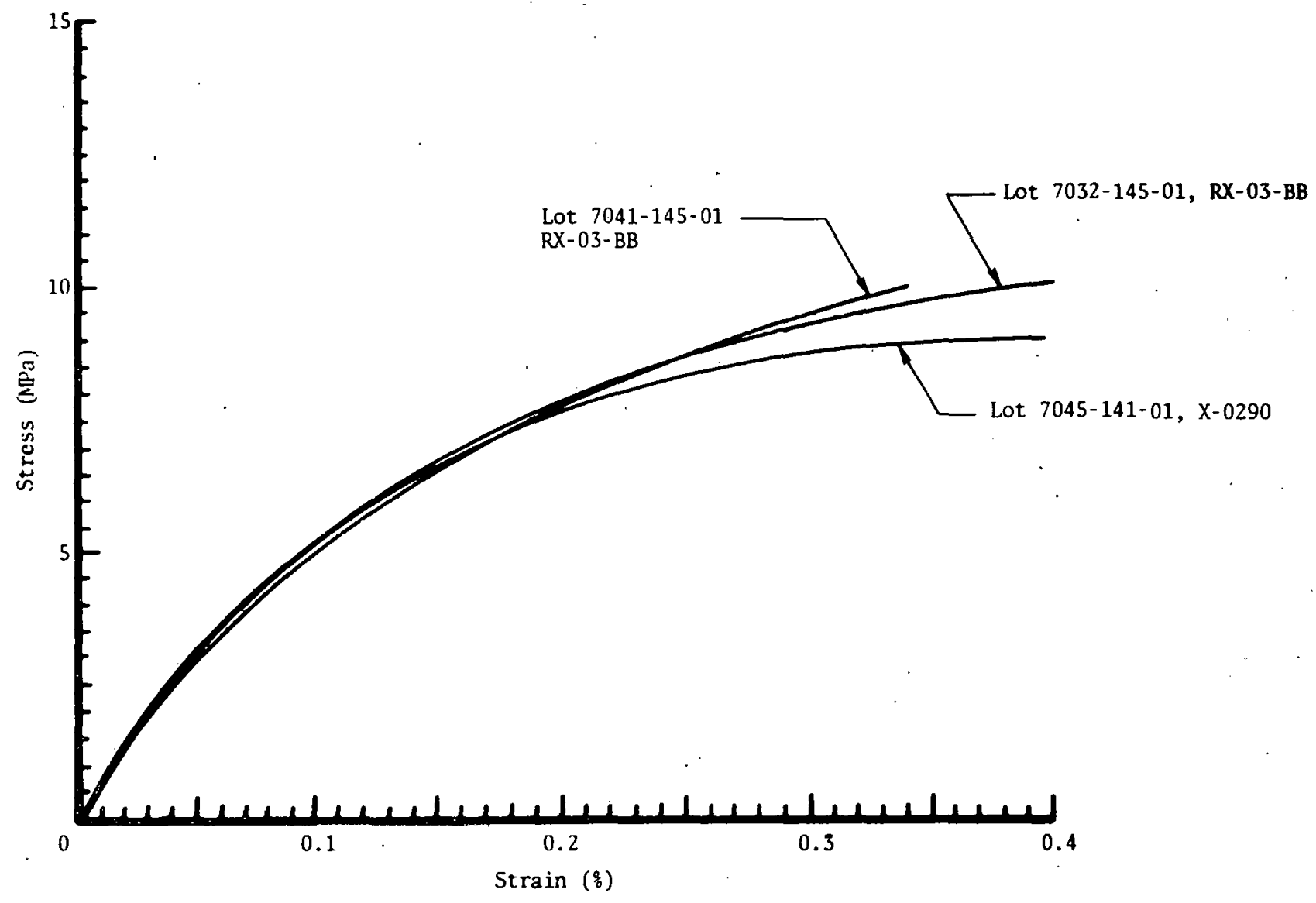

Fig. 2. Holston Process Method (Tensile Strength) 
Table II. Evaluation of Holston Ethyl Acetate Process - 300 Gallon Kettle - PBX Model at Pantex

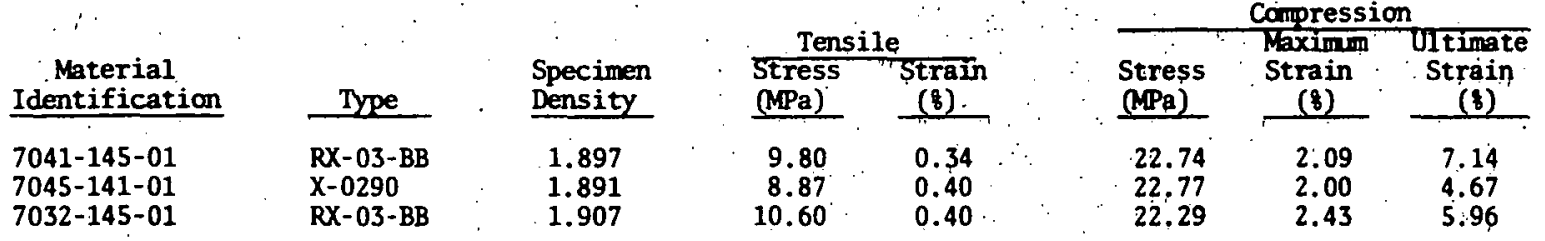

